\title{
New Trends in Student-Teacher Relationships on University Campuses in Cameroon: Situation and Challenges
}

\author{
Gilbert Tagne Safotso, PhD \\ Department of Foreign Applied Languages, Universty of Dschang, \\ Cameroon
}

Doi: 10.19044/ejes.v5no2a7

URL:http://dx.doi.org/10.19044/ejes.v5no2a7

\begin{abstract}
In Cameroon, the implementation of the Bachelor-Master-Doctorate system in the universities, which has been on for about ten years now, has drastically changed the nature of the relationships between students and teachers. The huge distance which used to exist between the learner and the teacher at university level has considerably reduced. The former conflicting relationships between the two partners are becoming more and more positive. Owing to the nature of the new tasks and roles that the new system entails, with the help of the ICTs, Cameroonian students can now approach, call / write to have appointments with their lecturers without any fear, even out of opening days and hours. Teachers do the same with their students. This new situation has led to new attitudes, behaviours, ways of thinking and challenges. From a sociological frame, this paper analyses the new trends in students and teachers relationships on Cameroonian university campuses and the new challenges that they involve.
\end{abstract}

Keywords: Relationships, roles, ICTs, trends, challenges.

\section{Introduction}

In society, the relationships between individuals are generally conflicting. The tendency is to dominate or persuade other people to accept one's views. The school milieu, which is a micro society, is not an exception to that rule. All kinds of behaviours have been reported in it: students' misbehaviour and rebellion against teachers and the system, lack of communication between teachers and learners, teachers' intolerance, lordly behaviour and tyranny, etc. Positive relationships between students and teachers are difficult to establish, but teachers and learners who have good communication, respect for each other in class, and show interest in teaching and learning can foster them in the classroom. Heather's (2010) remarks that 
we have a limited understanding of student-teacher relationships in that, most of our knowledge is about relationships for a particular population of students such as preschool, elementary school, middle school, or high school. This is embedded within knowledge about particular approach (e.g. attachment, motivation, or sociocultural). Nevertheless, given the impact of studentteacher relationships on teaching and learning outcome, considerable research has been conducted on the issue (McCormick \& Pressley, 1997; Prensky, 2005; Krause et al., 2006; Churchill et al., 2011, etc).

Hughes (2012) points out that the first generation research provided strong empirical support for the conclusion that a supportive teacher-student relationship promotes students' behavioural adjustment. The second generation research which aims to increase our understanding of the development of those relationships and the processes responsible for their effects is well underway. In a review of papers on teacher-student relationships and school adjustment, Hughes mentions two studies which argue that a close and supportive relationship with the teachers presumably serves as external source of stress regulation, allowing children to direct their energies toward engagement with tasks, peers, and teachers in the classroom (Little \& Kobak, 2003; Ahnert et al., 2012). Citing Huges \& Chen (2011: 278), Liberante (2012) argues that supportive and positive relationships between teachers and students ultimately promote "a sense of school belonging and encourage students to participate cooperatively in classroom activities". He also sees the intellectual quality, quality learning, environment and significance as central factors not only impacting learning, but also the quality of teacher-student interactions within the learning environment (Liberante, 2012:2).

In Cameroon, the implementation of the BMD (Bachelor-MasterDoctorate) system has for some time forced students and teachers on university campuses to adopt new behaviours, and to get into new types of relationships. This paper thus looks at the new trends of those relationships and the challenges they entail. To better understand the reasons for the new situation, it is important to have a brief look at the university system in Cameroon.

\section{A glimpse at the university system in Cameroon}

The history of the university system in Cameroon can be divided into four phases. The first goes from 1961 to 1971. It started with the creation of a complex known as Institut National d'Etudes Universitaires (National Institute for University Studies), transformed in 1962 into the Federal University of Cameroon. The aim of that university was to train massively in general knowledge to fill positions in the public service of the newly independent state. There was no selection to get into it, and enrolment was thus based only on obtaining a Baccalauréat / GCE Advanced Level. The creation of the Federal 
University was followed in 1967 by that of the University Centre for Health Sciences (CUSS), the Institute of Management, International School of Journalism of Yaounde (ESJY, 1970), the Institute of International Relations in 1971, and the Advanced School of Engineering in the same year (Njeuma et $a l ., 1999: 2$ ).

The second phase of the system took place in 1977 with the creation of the Buea University Centre for Language, Translation / Interpretation and the Arts; the Douala University Centre for Business Studies and the Training of Technical Education Teachers; the Dschang University Centre for Agricultural Sciences, and the Ngaoundéré University Centre for Food Science and Food Technology. It should be noted that, unlike the Federal University of Cameroon which enrolled massively, the specialised schools and university centres created from 1967 to 1977 enrolled very few students through a highly selective competitive entrance examinations. For example, 34, 886 students were enrolled at the University of Yaounde in 1990 against 58 at the Buea University Centre, 364 at the Ngaoundéré University Centre, 555 at the Dschang University Centre, and 645 at the Douala University Centre (Njeuma et al. ,1999: 4). That exceedingly high number of students with a limited number of lecturers (e.g. one lecturer for 252 students in the Faculty of Science) at the University of Yaounde caused a lot of frustration and discouragement among the teaching staff, resulting in very low success rate (about $30 \%$ ) and high drop out rates (Njeuma et al., 1999: 5). It is also important to mention that from 1961 to 1993 , the academic year was divided into three terms, just like in secondary school, and that an average mark of 10 over 20 was enough to pass.

In 1993, the only university of the country (University of Yaounde), with over 45,000 students for structures designed to enrol 5,000 had almost reached the threshold of implosion. Because of many students' strikes organised by a powerful movement called 'The Parliament', the government hastily created six full-fledged universities in January 1993. The creation of the universities of Buea, Douala, Dschang, Ngaoundéré, Yaounde I and Yaounde II to decongest the University of Yaounde is thus the third phase of the university system in Cameroon. One of the most important changes brought by the 1993 reforms was the re-organisation of the academic year into two semesters, and the introduction of the modular system. In the same year, the private sector was authorised to create university institutes. Since the six state universities were created without preparation, the teachers who had to launch them were transferred from the former University of Yaounde, with their frustrated and discouraged mentality. It should also be pointed out that it happened at the peak of the economic crisis, which led to the reduction of $70 \%$ of civil servants' salaries. So, although the newly created universities started with few students' enrolment, many teachers continued with their 
'Yaounde University mentality', i.e. frustrated irritated angry teachers, distant from their learners. Some of them openly expressed their anger for being transferred out of Yaounde where they originally applied to teach.

Njeuma et al. (1999: 2) note that the roots of present higher education problems in Cameroon stem from the method of developing the two types of higher education of the country. On the one hand, professional and technical education was very selective, admitting small numbers of students through highly competitive entrance examinations. On the other hand, massive nonselective admission of students was permitted into the university faculties to pursue general studies. "This produced in the universities a huge number of less qualified graduate who were not really employable".

The last phase of the university system in Cameroon (the current one), started timidly in the academic year 2007-2008, with the implementation of the BMD system. By then, except the University of Buea, in all the other six state universities, studies were organised into three cycles as follows: (1) the first cycle was subdivided into two sub cycles, with the first two years leading to DEUG (Diplome d'Etudes Universitaires), a kind of Diploma of General University Studies, followed by a one year Bachelor of Arts / Science Programme; (2) the second cycle consisted in a two year's Maitrise (Master) programme; (3) the third cycle started with a two year's DEA (Diplome d'Etudes Approfondies) or Advanced Diploma programme. A successful completion of that programme led to the Third Cycle Doctorate studies, which took a minimum of three years. It should be noted that, after the First Degree, the selection into the Maitrise, DEA or Third Cycle Doctorate programmes required at least an average of 12 on 20, which was extremely difficult to obtain. After the Third Cycle Doctorate, some rare lucky students who completed it with a good grade registered for a Doctorat d'Etat / PhD in the subjects that had qualified supervisors. In most cases, those candidates took an average of ten year to complete the programme.

The BMD system which has three simplified cycles that any average student can complete in eight to ten years was thus heartily welcome by the whole university community. Students could complete their university studies in a relatively short time, and lecturers who did not yet have a terminal degree could register to have it. With the new roles that the new system entailed, teachers and their students were bound to cooperate and to be closer to each other, to share knowledge/ research through internet. Both parties had to adapt to the new way of thinking and doing things. In this study, the focus is mainly on state universities. Professional / technical university institutes, where students intake is reduced, and the certification system is different is beyond its scope. 


\section{Method}

The data analysed was essentially collected through questionnaires and informal talks with some students and teachers of the Universities of Maroua, Yaounde I and Dschang. In total, 40 teachers' questionnaires and 120 students' ones were administered. 10 teachers and 15 students took part in the informal interviews. The teachers' questionnaire comprised two questions. The first question consisted in knowing the type of relationships that existed in their own days as university students between teachers and students, and what were the challenges of those days on the teacher's and student's side. The second question aimed to know the new types of relationships that now exist between students and teachers on university campuses, and the challenges that the new situation involves on both teacher's and student's side. The aim of the first question of the students' questionnaire was to find out if they know anything about the relationships between teachers and their students in the university days of their elders and teachers. The second question sought to get their opinion on the new type of relationships that now exist between their various teachers and them, and the demands that they impose on teachers and learners. The informal talks turned around the same issues with some teachers and students, but in a more relaxed atmosphere.

\section{Results}

The analysis is based on two different periods that correspond to two different lives on university campus in Cameroon, i.e. from 1961 to about 2008, and from 2008 to present. The period from 1961 to 2008 is that of the academic year divided into three terms and the modular system. During that period largely dominated by the University of Yaounde, the way of teaching and learning imposed a particular kind of behaviour to teachers and learners. Since 2008, the implementation of the BMD (Bachelor-Master-Doctorate) system has imposed a new type of relationship between students and teacher as examined below.

\section{Student-teacher relationships on Cameroonian university campuses from $1961 \approx 2008$}

From 1961, year of the creation of the first university in Cameroon to about 2008, when the implementation of the Bachelor-Masters-Doctorate started, the relationships between teachers and students were generally poor. Table 1 which follows summarises some aspects of them as perceived by students and teachers. 
Table 1. Perception of student-teacher relationships on Cameroonian university campuses from 1961 to about 2008

\begin{tabular}{|c|c|}
\hline Perception by teachers & Perception by students \\
\hline $\begin{array}{l}\text {-Distant, cool relationships } \\
\text { - Teachers were: } \\
\text { - formal stiff too proud duty conscious }\end{array}$ & $\begin{array}{l}\text { Students saw teachers as gods / lords and } \\
\text { behaved like their servants. }\end{array}$ \\
\hline $\begin{array}{l}\text { too full of themselves and looked down on } \\
\text { students }\end{array}$ & $\begin{array}{l}\text { Students were pure recipients of } \\
\text { knowledge. }\end{array}$ \\
\hline $\begin{array}{l}\cdot \text { had a self-sufficient attitude } \\
\text {-real master and had a lordly behaviour over } \\
\text { their learners } \\
\text {-had pure academic relationships with their } \\
\text { students and liked their work. }\end{array}$ & $\begin{array}{l}\text {-Students could not approach their teachers } \\
\text { - Fear and admiration of teachers } \\
\text { - Students had no right to complain. } \\
\text { - Strict, utter and total respect for teachers } \\
\text { - Total respect of teachers' instructions } \\
\cdot \text { Total submission to teachers } \\
\text { - Respect of teachers } \\
\text { - The teacher was a model. }\end{array}$ \\
\hline
\end{tabular}

The table above shows that, on Cameroonian university campuses, before the advent of the BMD system, teachers generally perceive the relationships between students and teachers as being of very low quality. Good relationships entail communication, collaboration, discussions, agreement and mutual respect. Yet, in those days teachers and students did not discuss anything, e.g. distant, cool relationships; too full of themselves and looked down on students. Students have the same perception of those relationships as illustrated by some of their answers: fear of teachers; strict, utter and total respect for teachers; total submission to teachers. In this kind of situation, teaching and learning are particularly difficult, as teachers strive to show to their learners how much they know and are important. As to students, it was the survival of the fittest or abandonment. The section below discusses the challenges relating to those relationships.

\section{Challenges relating to student-teacher's poor relationships from 1961 to about 2008}

The challenges relating to student-teacher's poor relationships were enormous. Teachers received insults and swearwords in amphitheatres, and many students dropped out after a few months or a year of studies. Some of those challenges gathered from teachers and students who took part in the study are summarised in the following table.

Table 2. Challenges relating to student-teacher's poor relationships

\begin{tabular}{ll}
\hline Teachers' challenges & Students' challenges \\
\hline Teachers had to: & Students had to: \\
$\cdot$ do a lot of research & - strive for excellence \\
· deliver good teaching & - be very courageous and courteous when \\
· worry about good results & they approach teachers \\
\hline
\end{tabular}




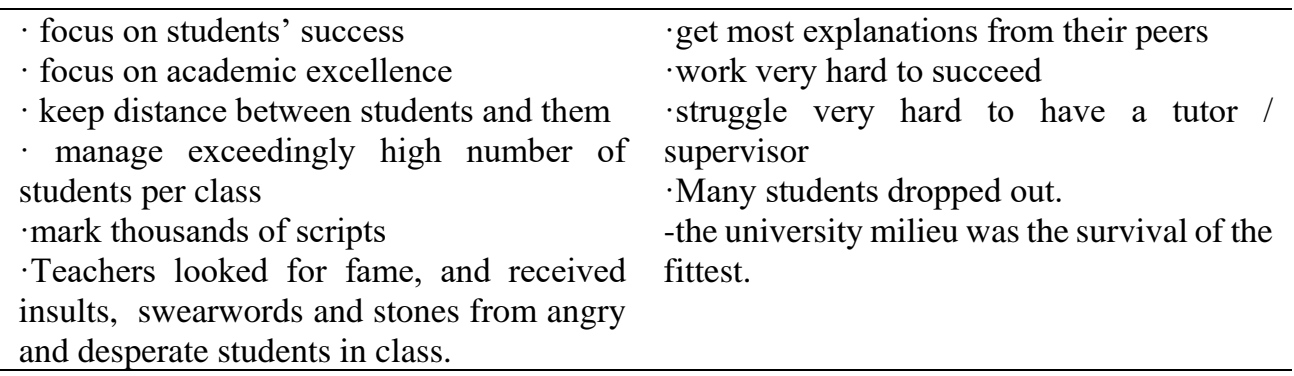

Table 2 indicates that the challenges relating to student-teacher's poor relationships were many on both teachers' and students' sides. For example, the teacher had to do a lot of research to prepare high quality lessons. Unfortunately, this yielded little result because of lack of communication and explanations, teachers' de-motivation and students' fear or disgust. Some teachers worried about their learners' result, but worked to improve it in a wrong way. For example, in the dark days of the University of Yoaunde, i. e. from mid 1980s to 1993, there were the well known way of stairs and concentric circles marking of students' scripts that some lecturers used to mark scripts in larger groups (3,000-5,000 students per class). The stairs marking consisted in throwing students' scripts over the stairs. Those which fell on the upper stair received a high mark such comprised between 14 and 15 on 20; the scripts which fell on the stairs in the middle had between 09 and 11 on 20 , and those which spread over the lower stairs (there were many scripts in that group) received between 05 and 08 on 20 . As to the concentric circles way of marking, the lecturer drew three of them on the floor, then threw the scripts into the air. Those which fell in the inner circle received between 14 and 15 on 20. The scripts which spread in the second circle had between 09 and 11 , and those which fell in the outer circles received between 05 and 08 on 20. Students were aware of those ill practices. But since no complaint was authorised, any failure was accepted as a fate. Some students who could not survive in such environment continued to go to class not to follow lessons, but to challenge or insult their lecturers. In amphitheatres, during lectures, at calm moments, it was common to hear insults such as 'idiot !', 'ta mère !' (your mum !), 'cul de ta mère !' (your mum's arse!), 'tes couilles' (your balls !). Many students simply abandoned their studies.

The tensed relationships, however, had some positive effects on the learners' side. For instance, university students knew that they had to work very hard, to do a lot of research to succeed. Those who passed their First Degree had to fight hard to have a tutor / supervisor. Indeed, in those days, lecturers accepted to work only with brilliant students and relatives. Mediocre and average students who resisted in the system had to abandon after the First Degree. Though that system was very harsh, students who succeeded through 
it were good, and well trained for the job market. The section below looks at the relationships between students and teachers on Cameroonian university campuses nowadays.

\section{New trends in student-teacher relationships on Cameroonian university campuses}

Since the beginning of the implementation of the BMD system in Cameroonian universities in 2008, a new trend in student-teacher relationships is being observed. Students have more rights and freedom, and the advent of ICTs (Information and Communications Technologies) has almost totally changed their perception of their teachers. Many lecturers have also adapted to the new situation, as summarised in Table 3 which follows.

Table 3. New trends in student-teacher relationships on Cameroonian university campuses (from 2008 - present)

\begin{tabular}{|c|c|}
\hline Perception by teachers & Perception by students \\
\hline Cordial friendly, fatherly, less formal & -Lack of respect for teachers \\
\hline -Familiarity with students & - Daring students \\
\hline -Mutual respect & -Students easily approach their teachers, \\
\hline -Teachers easily approachable & or catch-up tests \\
\hline -Exchange of phone numbers and e-mail & - Mutual trust \\
\hline boxes with students & -Students feel \\
\hline $\begin{array}{l}\text { Tolerance of students deviance. Proposition } \\
\text { of research topic to students }\end{array}$ & \\
\hline -Discussion of students' research topics & their lecture \\
\hline etent teachers & ails whenever they \\
\hline - Negligent dressing of teachers & want for academic matters. \\
\hline - Vulgar, casual behaviour of some teachers & - Intrusion into teachers' privacy \\
\hline with & $\cdot$ Righ \\
\hline - Sexual harassment by & $\begin{array}{l}\text { Some students launch complaints against } \\
\text { their lecturers. }\end{array}$ \\
\hline & -Sexual harassment by some lecturers \\
\hline
\end{tabular}

As can be observed in Table 3, since 2008, the relationships between students and teachers on Cameroonian university campuses have drastically changed. They have become more cordial and friendly. Students see them as particularly positive, as they can easily approach their teachers, call them whenever they want, send them text messages and electronic mails without any formality. Teachers show more respect and consideration to learners, kindly invite them to discuss their research topics, and seek their opinion before deciding. So, the huge distance which used to exist between students and their teachers has almost disappeared. But this shift in relationships sometimes leads into some exaggeration and deviance on both sides. Too much familiarity of some teachers with their students makes them vulgar in their eyes, as some teachers take the opportunity to 'sell' marks to students, or 
ask for beer from them. Some of them also use students' phone numbers to call them for non academic purposes, to sexually harass or disturb them at undue time. Some students do the same with their teachers' phone numbers and e-mail boxes, and even knock at their gates without any appointment, as discussed in the section on the new challenges below.

\section{Challenges relating to the new trends in student-teacher relationships on Cameroonian university campuses}

The new trends in student-teacher relationships have generated new challenges on teachers' and students' side. Table 4, which follows highlights some of them.

Table 4. Challenges relating to the new trends in student-teacher relationships on Cameroonian university campuses

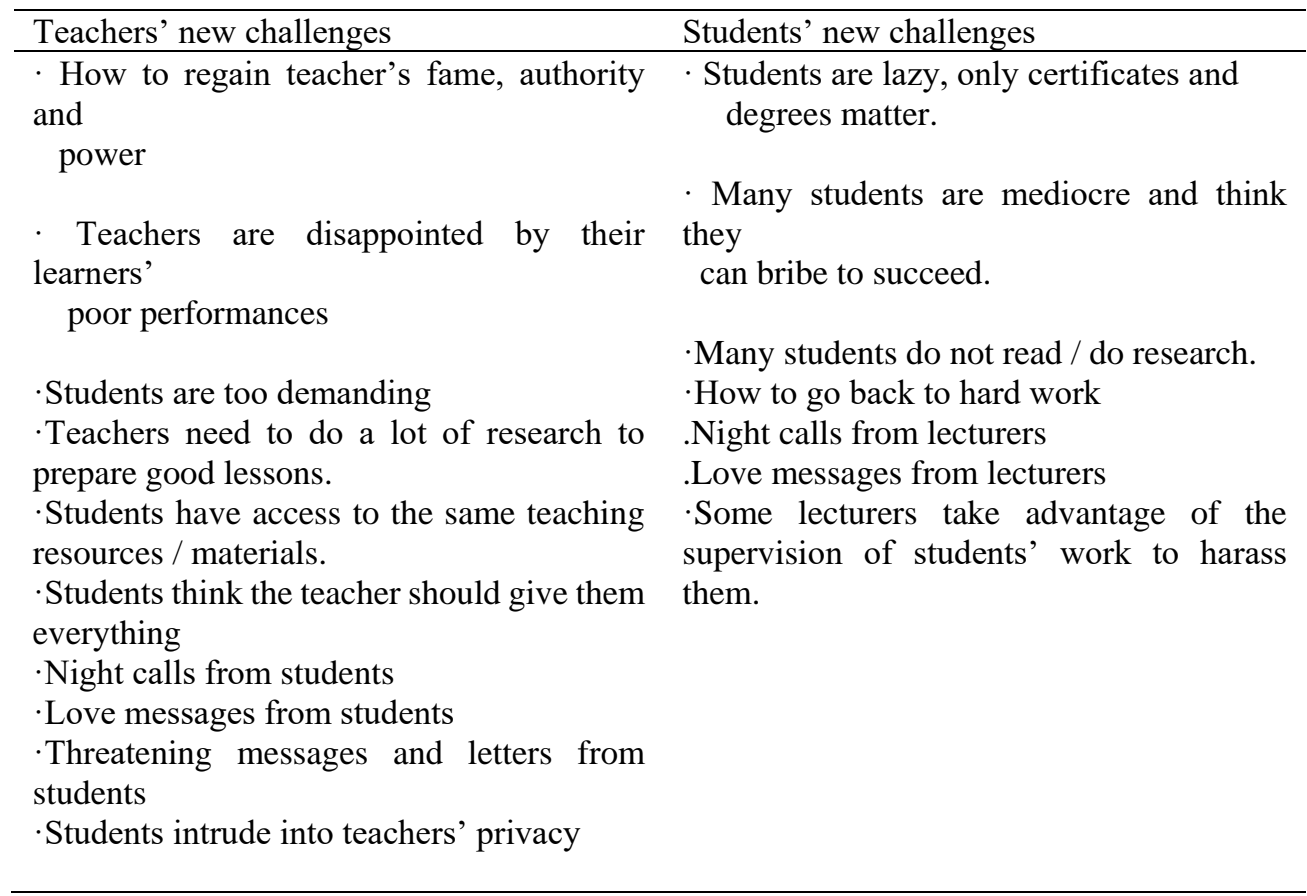

As a result of the exchange of telephone numbers and e-mail boxes with their students and many other new variables, the teachers and their learners now face many new types of challenges. As a matter of fact, with the development of ICTs and their use in education, those kinds of challenges were bound to occur. For example, with the use of the internet, students easily have access to some materials that their teachers use to prepare their lecture notes. This was almost totally impossible some years back, and that situation contributed to make students see their lecturers as $\operatorname{god}(\mathrm{s})$. With too much proximity and familiarity with their teachers, students are more and more 
aware of their weaknesses and strengths. For some students, it is just a question of knowing (or seeking to know) where a particular lecturer lives to take their academic problem to his / her house on Sunday or at night. Teachers complain more and more of such intrusion.

Like the teachers' challenges those of their learners in the new context are many. Given that the BMD system is that of units and credits, i. e. the student does not need an average mark of 10 on 20 to pass, but should validate almost all the units in the programme, some teachers use that situation to blackmail some students. It is not uncommon to hear students or groups of students complain of lecturers who 'sell marks' or harass students to make them pass the unit (s) they teach. Female students generally complain of some lecturers who invite them to hotels or their houses as a condition to pass their units.

\section{Conclusion}

In conclusion, the relationships between students and teachers were very poor on Cameroonian university campuses from 1961 to 2008 due to the mentality, the teaching methods, the various roles and tasks of that time. There was a huge distance between the teacher and the learner. There was almost no communication between them, and only professional relationships were permitted. Students were pure recipients of knowledge. They saw teachers as lords / gods, and had no right to complain. Paradoxically, the best students ever trained in Cameroonian universities were at that period though the failure and drop out rates were very high. On campus, some people continue to regret the disappearance of that period though acknowledging its tyranny and other shortcomings.

The new trends in student-teacher relationships are normally what they should be, i.e. cooperation and communication between the two partners, mutual respect and trust, students' right to complain, etc. But the new situation at times leads to some exaggeration, deviance and misunderstanding on both sides. While in the new context some students think that they have right to all -even passing without studying, some lecturers have become too close and even fatherly to them. This results in laziness and too much tolerance on both sides. The BMD system, with the new roles and responsibilities that it imposes is without doubt what the Cameroonian university system needs at the dawn of the $21^{\text {st }}$ century. To make it more effective and clarify each partner's role, regular workshops and seminars should be organised by academic authorities on the issue. Booklets (a kind of teachers' and students' dos and don'ts) that state and clarify the teachers' rights and obligations as well as those of students should be produced by each university and put at the disposal of teachers and students. If this could be done, it may reduce the confusion so far observed on both sides and foster the quality of student-teacher relationships. 
Note: An early version of this paper was presented at the Second Canadian Conference on Advances in Education and Technology, EduTeach, in Toronto, 29-31 July 2017.

\section{References:}

1. Ahnert, Lieselotte, et al. (2012). Student-teacher Relationships and classroom Climate in First Grade: How they relate to students' stress regulation? Attachment \& HumanDevelopment, 19 (3), 249-263. doi: 10.1080/14616734.2012.673277.

2. Chrchill et al. (2011). Teaching: Making a difference. Milton QLD: Wiley \& Sons.

3. Heather, A. Davis (2010). Conceptualizing the Role and Influence of Student-Teacher Relationships on Children's Social and Cognitive Development. Educational Psychologist, 38 (4), 207-234. DOI: http://dx.doi.org/10.1207/S15326985EP3804_2.

4. Hughes, Jan N.(2012).Teacher-Student Relationships and School Adjustment: Progress and Remaining Challenges. Attachment \& Human Development, 14 (3), 319-327.

5. DOI: http://dx.doi.org/10.1080/14616734.2012.672288.

6. Hughes, J. N. \& Chen, Q. (2011). Reciprocal effects of student-teacher and student-peer Relatedness: Effects on academic self-efficacy. Journal of Applied Developmental Psychology, 32 (5), 278-287.

7. Krause, K. Bochner, S. \& Duchesne, S. (2006). Educational Psychology: For learning and Teaching (2 $2^{\text {nd }}$ ed.). Melbourne: Thomson Learning.

8. Liberante, Lauren (2012);The Importance of Teacher- Student Relationship as Explored Through the Lens of NSW Quality Teaching Model. Journal of Student Engagement: Education Matters, 2(1), 2-9.

9. Little, M. \& Kobak, R. (2003). Emotional Security with Teachers and Children's Stress Reality: A Comparison of Special-education and regular-education classrooms. Journal of Clinical Child \& Adolescent Psychology, 32 (1): 127-137. DOI: 10.1207/ S15374424JCCP3201 12.

10. McCormick, C. B. \& Pressley, M. (1997). Educational Psychology: Leaning, instruction, assessment. New York: Longman.

11. Njeuma, D. L. (1999). Reforming a National System of Higher Education: The Case of Cameroon. Washington, DC: ADEA Working Group on Higher Education, the World Bank.

12. Prensky, M. (2005). Engage me or enrage me: What today's learners demand. Educause Review, 40 (5), 60-64. 